\title{
Analisis Sistem Informasi Akuntansi Penggajian Pada CV ABC di Jawa Tengah
}

\author{
Desi Trijayanti*, Wahyu Pramesti \\ Fakultas Ekonomi dan Bisnis Islam, IAIN Surakarta, Surakarta, Indonesia
}

This research was conducted at CV ABC which is engaged in the furniture industry. In managing the payroll system this company is still less effective. It can be seen from several salary payment activities to employees who still often make mistakes in the process of calculating salaries and employee attendance records. In addition, in the process of paying salaries to employees, they often experience late payments. The purpose of this study is to analyze the payroll accounting information system in the company which is expected to help resolve the problems faced by the company. The research method used in this study is a qualitative descriptive research method. The thing that will be done by the researcher is to describe the use of payroll accounting system on CV ABC. The conclusion of this study is that the payroll system on CV ABC is already good because it has used a computerized system. The internal control in the payroll process is still weak because there are still division of tasks and responsibilities of each part that is unclear, namely there is a double duty and interdependence in working tasks, besides that supervision is still lacking for activities that should be routinely checked or corrected.

\section{Keywords: Payroll information system, Procedures, Computerized}

OPEN ACCESS ISSN 2548-3501 (online)

Edited by: Eny Maryanti

Reviewed by: Eva Wany

*Correspondence: Desi Trijayanti

desi_trijayanti@yahoo.com

Received: 20 April 2019 Accepted: 15 Mei 2019 Published: 31 Juli 2019

Citation:

DT and WP (2019) Analisis Sistem

Informasi Akuntansi Penggajian

Pada CV ABC di Jawa Tengah. Journal of Accounting Science. 3:2. doi: 10.21070/jas.v3i2.2768
Penelitian ini dilakukan pada CV ABC sebegai suatu perusahaan yang bergerah di bidang furnitur. Dalam mengelola sistem penggajian, perusahaan ini berlangsung belum cukup efektif. Hal tersebut nampak dari beberapa kejadian ketika pegawai menerima upah yang kurang tepat dan kejadian lain mengenai ketidaktepatan dalam menghitung jam kerja. Sebagai tambahan, keterlambatan pemberian upah pun juga kadang terjadi pada CV ABC. Penelitian ini bertujuan untuk menganalisis sistem informasi akuntansi penggajian pada CV ABC yang diharapkan mampu memberi solusi atas masalah yang dihadapi oleh perusahaan. Peneliti akan memaparkan sistem yang berjalan pada CV ABC. Hasil dari penelitian ini menunjukkan bahwa sistem akuntansi penggajian pada CV ABC sudah cukup baik karena sudah terkomputerisasi. Di sisi lain, pengendalian internal dalam proses penggajian masih cukup lemah karena masih terdapat tugas dan tanggungjawab dari masing-masing bagian yang belum cukup jelas, seperti diantaranta terdapat perangkapan tugas dan saling ketergantungan antar tugas, disamping itu juga terdapat manajer yang masih belum bekerja secara optimal dalam hal pengecekan secara rutin aktivitas penggajian.

Keywords: Sistem informasi penggajian, Prosedur, Terkomputerisasi 


\section{PENDAHULUAN}

Setiap perusahaan memiliki sumber daya seperti sumber daya alam, sumber daya modal dan sumber daya manusia yang dapat dimanfaatkan untuk mencapai tujuan perusahaan. Sumber daya manusia merupakan salah satu faktor penting yang harus dimiliki oleh setiap perusahaan. Peran serta sumber daya manusia sebagai penyangga utama dalam penggerak organisasi sangatlah mendukung pencapaian tujuan perusahaan. Untuk meningkatkan kinerja sumber daya manusia sebagai bentuk pencapaian tujuan perusahaan maka perusahaan perlu memberikan balas jasa yang sesuai.

Pemberian balas jasa berupa pembayaran gaji kepada karyawan perusahaan harus dilakukan secara sistematis dan diharapkan tidak akan terdapat kesalahan dalam prosedur penggajian. Sehingga perusahaan sangat membutuhkan sistem penggajian yang baik, hal tersebut akan memudahkan bagi perusahaan untuk melakukan proses pembayaran gaji secara tepat dan efisien.

CV ABC adalah perusahaan yang bergerak di bidang industri mebel dengan jumlah karyawan sekitar 314 orang. Dengan jumlah karyawan yang relatif banyak, CV ABC masih memiliki beberapa kekurangan dalam sistem penggajiannya. Hal tersebut dapat dilihat dari hasil pengamatan peneliti selama melakukan observasi pada tahun 2017 sampai tahun 2018. Kejadian berupa beberapa kali karyawan CV ABC yang seharusnya menerima pembayaran gaji setiap minggunya pada hari Jumat, mereka menerima pembayaran kurang atas uang gaji yang seharusnya diberikan atau beberapa jumlah jam hadir karyawan tercatat kurang dalam penghitungan gaji yang dilakukan perusahaan.

Pengamatan lain yang peneliti dapatkan bahwa beberapa karyawan $\mathrm{CV}$ ABC yang menerima pembayaran gaji setiap minggunya pada hari Jum'at melalui transfer ke rekening masing-masing karyawan, bahwa sering beberapa kali karyawan tersebut mengeluhkan atas keterlambatan pembayaran gaji yang seharusnya mereka terima pada hari Jumat. Waktu keterlambatan pembayaran gaji yang dialami oleh setiap karyawan tersebut berbeda-beda, ada yang mengalami waktu keterlambatan tiga sampai empat hari setelah tanggal pembayaran gaji.

Menurut Widjajanto (2001); Bachtiar (2012) "sistem informasi adalah suatu bentuk formulir, peralatan (komputer beserta alat komunikasi), tenaga pelaksana dan laporan yang terkoordinasikan secara erat untuk mentransformasikan data keuangan menjadi informasi keuangan yang dibutuhkan". Romney and Steinbart (2017) membagi komponen sistem informasi akuntansi menjadi enam bagian yaitu:

1. Orang yang menggunakan sistem.

2. Prosedur yang digunakan untuk mengumpulkan, memproses dan menyimpan data.

3. Data mengenai organisasi dan aktivitas bisnisnya.

4. Perangkat lunak yang digunakan untuk mengolah data.
5. Infrastruktur teknologi informasi yang digunakan dalam sistem informasi akuntansi.

6. Pengendalian internal dalam sistem informasi akuntansi.

Penelitian yang dilakukan oleh Danke (2012) yang "menganalisis sistem informasi akuntansi penggajian untuk mendukung pengendalian internal pada perusahaan plastik injection menemukan hasil bahwa ketidakakuratan informasi dan kesalahan penggajian disebabkan karena kurangnya dokumen yang digunakan serta adanya pengerjaan tugas dan tanggung jawab yang masih tidak sesuai dengan tugas masing-masing bagian". Terkait dengan hal tersebut bahwa untuk memperoleh keakuratan informasi dan untuk meminimalisir kesalahan dalam proses penggajian dapat dilakukan dengan pemisahan tugas dan tanggung jawab pada masing-masing bagian secara jelas. Tujuan penelitian ini adalah untuk mengetahui sistem informasi akuntansi penggajian yang diterapkan oleh CV ABC di Jawa Tengah.

Bachtiar (2012)melakukan penelitian yang mengambil obyek pada PT DIS mengenai sistem informasi akuntansi penggajian yang menunjukkan hasil bahwa pada PT DIS proses penginputan data secara manual dari kartu jam kerja dan data rekapitulasi gaji karyawan ke MS-Excel rawan terjadi kesalahan input data. Selain itu, data pada Ms-Excel PT DIS tidak dapat menyediakan database karyawan karena jumlah karyawan sangat banyak yakni 2500. Selain itu, ketiadaan pembatasan akses terhadap sumber daya komputer membuat data rawan dimanipulasi. Terakhir, media perekaman kehadiran karyawan dengan menggunakan check clock yang menjadikannya rawan presensi dilakukan oleh karyawan lain.

Hasil yang ditemukan Suryanto (2011) yang mengkaji sistem penggajian pada suatu hotel yang belum menggunakan sistem terkomputerisasi dalam sistem penggajian menemukan bahwa terdapat risiki manipulasi data kehadiran dan jumlah penggajian karena sistem yang masih manual serta laporan pembayaran gaji yang belum lengkap.

Menurut Danke (2012) yang melakukan penelitian pada CV Mustika Indah Kencana, menemukan bahwa "pada CV tersebut masih terdapat kekurangan pada dokumen sehingga menyebabkan ketidakakuratan informasi dan kesalahan penggajian. Selain itu dokumen yang dimiliki masih belum lengkap sehingga tidak bisa menyimpan data dan memberikan informasi yang memadai apabila dibutuhkan. Hal lain berupa, kadang terdapat kesalahan penghitungan gaji yang diberikan kepada karyawan. Yang terakhir masih terdapatnya pengerjaan tugas yang tidak sesui dengan tupoksinya".

Di tahun yang sama, hasil yang ditemukan oleh Novena (2012) menunjukkan bahwa "sistem yang ada PT PD kurang sesuia dengan perkembangan jaman karena masih menggunakan mesin Check Clock yang memungkinkan terjadinya kecurangan, serta penghitungannya masih secara manual sehingga memungkinkan terjadi kesalahan. Disamping itu juga ketiadaan database pegawai sedangkan PT PD memiliki jumlah pegawai yang banyak. Sehingga disarankan untuk mengelola sistem penggajian dengan suatu sistem yang terkomput- 
erisasi untuk menyelenggarakan sistem penggajian.”

Dalam penelitian Thite and Shandu (2014) menemukan" alasan kegagalan proyek implementasi penggajian karena kurangnya kejelasan tentang persyaratan bisnis, analisis kebutuhan yang buruk, ruang lingkup proyek tidak jelas, dan kebingunan peran dan tanggungjawab antar pemangku kepentingan. Alasan lain ditambahkan bahwa kurangnya keterlibatan pengguna dalam desain sistem dan penilaian risiko yang kurang memadai”.

Menurut Saraswati (2014), dalam hasil penelitiannya memperoleh bukti bahwa" masih sering terjadi kecurangan pada saat karyawan melakukan perekaman waktu kehadiran menggunakan clock card, terdapat juga perangkapan fungsi pada bagian administrasi HRD di PT. Japfa Comfeed Indonesia, Tbk Kantor Cabang Sidoarjo”.

Penelitian lain yang dilakukan Agrianto (2014) pada PT Duta Paper Progen Pasuruan menunjukkan bahwa "penerapan sistem akuntansi penggajian dan pengupahan sudah cukup baik dan mendukung pengendalian internal. Hal tersebut ditunjukkan dengan adanya pemisahan fungsi antara pembuat daftar gaji dan fungsi pembayaran gaji”.

Mayasari (2015) menemukan bahwa pada "PT Aditya Buana Inter Sungailiat Bangka sebelumnya menggunakan sistem manual dalam sistem informasi penggajian karyawan dan beralih menggunakan sistem yang terkomputerisasi sehingga menjadikan proses pengolahan data penggajian menjadi lebih cepat dan efisien".

Dari latar belakang tersebut penelitian ini bertujuan untuk menganalisis sistem informasi akuntansi penggajian pada $\mathrm{CV}$ ABC yang diharapkan mampu memberi solusi atas masalah yang dihadapi oleh perusahaan.

\section{METODE PENELITIAN}

\section{Ruang Lingkup Penelitian}

Penelitian ini merupakan penelitian kualitatif. Data yang digunakan adalah data primer dan data sekunder. Data primer diperoleh melalui wawancara secara langsung kepada responden penelitian yaitu Manajer Keuangan, Manajer Produksi, Bagian Akuntansi dan Keuangan, HRD, Admin Produksi dan Karyawan. Data primer tersebut meliputi struktur organisasi $\mathrm{CV}$ ABC, job description, sistem dan prosedur penggajian $\mathrm{CV}$ $\mathrm{ABC}$ dan hal-hal lain yang berkaitan dengan kegiatan penggajian. Data sekunder dalam penelitian ini meliputi dokumen dan catatan penggajian pada CV ABC.

\section{Bahan dan Alat Utama}

Untuk memperoleh data penelitian yang dibutuhkan, peneliti terlebih dahulu membuat daftar pertanyaan yang nantinya ditujukan kepada responden penelitian.

\section{Teknik Pengumpulan Data}

Teknik pengumpulan data yang digunakan dalam penelitian ini ada tiga yaitu:

1. Wawancara langsung kepada responden penelitian, dimana peneliti mengajukan pertanyaan yang nantinya akan dijawab langsung oleh responden penelitian.

2. Observasi, dimana peneliti mengamati keseluruhan mengenai kegiatan operasional perusahaan yang berkaitan dengan proses penggajian.

3. Dokumentasi, dimana peneliti mengumpulkan dan mempelajari dokumen terkait kegiatan penggajian.

\section{Teknik Analisis Data}

Teknik analisis data dalam penelitian ini meliputi:

1. Menganalisis struktur organisasi $\mathrm{CV}$ ABC untuk melihat apakah struktur tersebut menunjang untuk dilaksankannya sistem penggajian yang baik.

2. Melakukan perancangan flowchart bagi sistem penggajian perusahaan.

3. Mengevaluasi sistem dan prosedur penggajian perusahaan.

4. Menganalisis dokumen dan pengendalian internal yang dimiliki oleh perusahaan.

\section{HASIL DAN PEMBAHASAN}

\section{Prosedur Sistem Akuntansi Penggajian Pada CV ABC di Jawa Tengah}

1. Prosedur Penerimaan dan Penempatan Karyawan .Prosedur ini dilakukan oleh fungsi kepegawaian yaitu bertugas mencari, menyeleksi dan menempatkan karyawan baru sesuai dengan keterampilan dan pendidikan.

2. Prosedur Pencatatan Waktu Hadir. Pencatatan waktu hadir menggunakan alat fingerprint. Prosedur ini dilakukan oleh fungsi pencatat waktu hadir karyawan.

3. Prosedur Penghitungan Gaji.Penghitungan gaji menggunakan microsoft excel yang dilakukan oleh bagian akuntansi dan keuangan CV ABC.

4. Prosedur Pembayaran Gaji. Pembayaran gaji dilakukan melalui transfer rekening dan pembayaran secara tunai. Pembayaran gaji karyawan dilakukan oleh fungsi keuangan.

\section{Fungsi Terkait Dalam Sistem Akuntansi Penggajian Pada CV ABC di Jawa Tengah}

1. Fungsi Kepegawaian. Fungsi ini dilakukan oleh Manajer Keuangan untuk pabrik 1 dan Manajer Produksi untuk pabrik 2. Fungsi ini bertugas mencari, menyeleksi dan menempatkan karyawan baru serta melakukan promosi, kenaikan pangkat, mutasi, pemberhentian karyawan dan penetapan kenaikan gaji karyawan perusahaan. 
2. Fungsi Pencatatan Waktu Hadir Karyawan.Fungsi ini dilakukan oleh HRD untuk pabrik 1 dan Admin Produksi untuk pabrik 2. Pencatatan waktu hadir karyawan perusahaan menggunakan alat fingerprint.

3. Fungsi Pembuat Daftar Gaji.Fungsi ini dilakukan oleh bagian akuntansi dan keuangan CV ABC yaitu melakukan penghitungan gaji dan upah berisi gaji kotor, gaji bersih, tunjangan dan potongan yang diberikan kepada setiap karyawan.

4. Fungsi Akuntansi. Fungsi ini dilakukan oleh bagian akuntansi dan keuangan CV ABC yaitu melakukan pencatatan transaksi-transaksi keuangan yang berkaitan dengan pembayaran gaji.

5. Fungsi Keuangan. Fungsi ini dilakukan oleh bagian akuntansi dan keuangan CV ABC yaitu melakukan proses pembayaran gaji secara tunai atau transfer rekening.

\section{Dokumen yang Digunakan Dalam Sistem Akuntansi Peng- gajian CV ABC di Jawa Tengah}

Dokumen yang digunakan adalah dokumen pendukung perubahan gaji dan upah, data karyawan, kartu jam hadir, kartu jam kerja, daftar gaji dan daftar upah, rekap daftar gaji dan rekap daftar upah, slip gaji dan upah, tanda bukti penerimaan gaji dan upah dan rekening koran bank.

Catatan Akuntansi yang Digunakan Dalam Sistem Akuntansi Penggajian CV ABC di Jawa Tengah

1. Jurnal Umum. Jurnal umum digunakan untuk mencatat pengeluaran biaya gaji karyawan. Pencatatan transaksi ke jurnal umum menggunakan aplikasi My Biz.

2. Daftar Rekapitulasi Pembayaran Gaji. Daftar ini berisi rekapitulasi pembayaran gaji yang dilakukan menggunakan aplikasi microsoft excel.

3. Database penggajian. Database ini berisikan informasi penghitungan gaji seluruh karyawan yang tersimpan urut sesuai tanggal dalam aplikasi microsoft excel.

Pengendalian Internal Dalam Sistem Akuntansi Penggajian CV ABC di Jawa Tengah Organisasi

1. Pembuat daftar gaji dan tugas fungsi keuangan dilakukan oleh satu orang yaitu bagian akuntansi dan keuangan $\mathrm{CV}$ $\mathrm{ABC}$.

2. Pencatat waktu hadir pabrik 2 yaitu admin produksi masih melaksanakan tugas dan tanggung jawab dalam kegiatan operasional.

\section{Sistem Otorisasi}

1. Seluruh karyawan yang ada di CV ABC tidak memiliki surat keputusan pengangkatan sebagai karyawan, perusahaan hanya mengeluarkan surat lanjut tidaknya bekerja setelah masa training karyawan selama 3 bulan.

2. Setiap perubahan atas gaji didasarkan pada surat keputusan komisaris perusahaan.
3. Setiap ada potongan atas gaji selain $\mathrm{PPh}$ diotorisasi oleh fungsi kepegawaian.

4. Tidak perlu adanya otorisasi kartu jam hadir karena perusahaan telah menggunakan fingerprint.

5. Kegiatan lembur dikerjakan atas perintah lembur dari manajer produksi.

6. Daftar gaji yang selesai dibuat tidak dilakukan otorisasi pihak yang berwenang lagi, karena selanjutnya langsung pada proses pembayaran.

7. Perusahaan tidak memerlukan bukti kas keluar, karena pembayaran yang dilakukan yaitu dengan memberikan uang tunai beserta slip gaji dan pembayaran langsung lewat transfer rekening.

\section{Prosedur Pencatatan}

1. $\mathrm{CV}$ ABC tidak menggunakan catatan penghasilan karyawan, mereka hanya memiliki rekap penghasilan karyawan keseluruhan selama satu tahun.

2. Tarif upah tidak lagi dilakukan proses verifikasi untuk menjamin ketelitiannya.

\section{Praktik yang Sehat}

1. Praktik yang sehat yang dilakukan hanyalah proses pencatatan waktu hadir, itupun menggunakan fingerprint yang tidak perlu proses pengawasan.

2. Ketidaksesuaian praktiknya yaitu perusahaan tidak melakukan proses verifikasi kembali sebelum daftar gaji digunakan sebagai dasar pembayaran gaji.

3. Perusahaan juga tidak melakukan proses rekonsiliasi dalam proses penghitungan pajaknya.

\section{Pembahasan}

Dari hasil penelitian yang peneliti lakukan di lapangan serta setelah dibandingkan dengan teori yang dipelajari maka peneliti membuat beberapa evaluasi. Evaluasi yang pertama terhadap prosedur dalam sistem akuntansi penggajian. Prosedur yang dilakukan CV ABC adalah prosedur penerimaan dan penempatan karyawan, prosedur pencatatan waktu hadir, prosedur penghitungan gaji dan prosedur pembayaran gaji. Sedangkan prosedur sistem penggajian dalam Mulyadi (2016) adalah" prosedur pencatatan waktu hadir, prosedur pembuatan daftar gaji, prosedur distribusi biaya gaji, prosedur pembuatan bukti kas keluar dan prosedur pembayaran gaji”. Terdapat beberapa prosedur yang tidak sesuai dengan teori misalnya prosedur pembuatan daftar gaji, hal itu dikarenakan proses pembuatan daftar gaji pada CV ABC terhubung langsung dengan proses penghitungan gaji. Sedangkan untuk prosedur distribusi biaya gaji dan prosedur pembuatan bukti kasi keluar tidak ada pada CV ABC karena perusahaan tidak melakukan proses tersebut. Namun secara keseluruhan prosedur yang dilakukan sudah baik karena terdapat urutan prosedur yang jelas dalam kegiatan penggajian. 
Evaluasi yang kedua terhadap fungsi terkait dalam sistem akuntansi penggajian. Fungsi terkait dalam penggajian $\mathrm{CV}$ ABC adalah fungsi kepegawaian, fungsi pencatatan waktu hadir karyawan, fungsi pembuat daftar gaji, fungsi akuntansi dan fungsi keuangan. Sedangkan Menurut teori Mulyadi (2016) "fungsi terkait yaitu fungsi kepegawaian, fungsi pencatat waktu, fungsi pembuat daftar gaji, fungsi akuntansi dan fungsi keuangan". Dari praktik yang ada pada CV ABC dengan teori yang ada bahwa fungsi terkait yang menjalankan kegiatan penggajian sudah lengkap, namun beberapa fungsi masih dikerjakan oleh satu bagian yang sama yaitu fungsi pembuat daftar gaji dan fungsi pembayaran gaji yang dikerjakan oleh bagian akuntansi dan keuangan CV ABC.

Evaluasi selanjutnya terhadap dokumen yang digunakan dalam sistem akuntansi penggajian. Dokumen yang digunakan oleh $\mathrm{CV}$ ABC adalah dokumen pendukung perubahan gaji dan upah, data karyawan, kartu jam hadir, kartu jam kerja, daftar gaji dan daftar upah, rekap daftar gaji dan rekap daftar upah, slip gaji dan upah, tanda bukti penerimaan gaji dan upah dan rekening koran bank. Sedangkan menurut teori Mulyadi (2016) "dokumen yang digunakan yaitu dokumen pendukung perubahan gaji dan upah, kartu jam hadir, kartu jam kerja, daftar gaji dan upah, rekap daftar gaji dan rekap daftar upah, surat pernyataan gaji dan upah, amplop gaji dan upah dan bukti kas keluar". Terdapat beberapa dokumen dalam teori Mulyadi (2016) yang tidak digunakan seperti surat pernyataan gaji dan upah, amplop dan bukti kas keluar, hal itu karena $\mathrm{CV} A B C$ dalam proses pembayaran gaji tidak menggunakan amplop dan bukti kas keluar, CV ABC melakukan pembayaran secara tunai dengan slip beserta uang tunai dan transfer lewat rekening masing-masing karyawan.Evaluasi terhadap catatan yang digunakan dalam sistem akuntansi penggajian menyoroti mengenai catatan yang digunakan. Catatan yang digunakan pada $\mathrm{CV}$ ABC adalah jurnal umum, daftar rekapitulasi pembayaran gaji dan database penggajian. Sedangkan dalam teori Mulyadi (2016) "catatan yang digunakan mencakup jurnal umum, kartu harga pokok produk, kartu biaya dan kartu penghasilan karyawan". Terdapat dokumen yang tidak ada dalam praktiknya seperti kartu harga pokok produk, kartu biaya dan kartu penghasilan karyawan. Hal itu karena perusahaan tidak menggunakan dokumen tersebut.

Selanjutnya evaluasi bagan alir sistem akuntansi pengga-

\section{REFERENCES}

Agrianto, R. S. (2014). Analisis Sistem Akuntansi Penggajian dan Pengupahan dalam Upaya Meningkatkan Efektivitas Pengendalian Internal Perusahaan (Studi Kasus pada PT Duta Paper Prigen Pasuruan). Jurnal Administrasi Bisnis

Bachtiar, E. (2012). Perancangan Sistem Informasi Akuntansi dengan Menggunakan Database Karyawan untuk Meningkatkan Keakuratan dalam Melakukan Perhitungan Penggajian pada PT DIS. Jurnal Ilmiah Mahasiswa Akuntansi 01, 86-89.

Danke, Y. (2012). Analisis perancangan sistem informasi akuntansi pada siklus penggajian dalam rangka efektivitas pengendalian internal (Studi kasus pada perusahaan Plastik Injection). Jurnal Ilmiah Mahasiswa Akuntansi 1, 22-26. jian. Dalam praktiknya bagan alir sistem penggajian CV ABC sudah jelas alurnya, namun dalam proses kegiatan penggajian masih terdapat kurangnya kegiatan pengkoreksian ulang yang seharusnya dilakukan yaitu mencakup proses pencatatan, perhitungan dan pembayaran gaji. Evaluasi Terakhir pengendalian internal dalam sistem akuntansi penggajian. Dalam praktiknya pengendalian internal yang ada pada kegiatan penggajian $\mathrm{CV}$ ABC tidak sesuai, hal itu dilihat dari masih banyak hal yang tidak sesuai dengan teori yang digunakan yaitu untuk pengendalian internal "organisasi" masih terdapat perangkapan tugas yang dilakukan oleh petugas bagian akuntansi dan keuangan dan admin produksi. Dalam "sistem otorisasi" terdapat kegiatan yang tidak dilakukan otorisasi kembali yaitu daftar gaji, seharusnya dilakukan otorisasi kembali untuk menjamin kebenaran data yang ada. Untuk "prosedur pencatatan" ada data yang juga tidak dilakukan verifikasi kembali yaitu data tarif upah. Dalam praktik yang sehatpun juga sama tidak dilakukan proses verifikasi dokumen kembali.

\section{KESIMPULAN}

Kesimpulan yang dapat diambil dari hasil penelitian ini adalah sistem penggajian pada CV ABC sudah baik karena sudah menggunakan sistem komputerisasi. Sedangkan untuk pengendalian internal dalam proses penggajian masih lemah karena masih terdapat pembagian tugas dan tanggung jawab masing-masing bagian yang belum jelas yaitu terdapat perangkapan tugas dan saling ketergantungan dalam mengerjakan tugas. Selain itu pengawasan yang masih kurang untuk kegiatan yang seharusnya dilakukan pengecekan atau koreksi secara rutin

\section{UCAPAN TERIMA KASIH}

Peneliti mengucapkan terima kasih kepada seluruh pihak dari CV ABC mulai dari karyawan-karyawan pabrik, staf accounting, dan manajer area yang telah berkenan memberikan kontribusi, kesempatan observasi, dan informasi sehingga dapat kami gunakan untuk penyusunan dan analisis dalam penelitian ini.

Mayasari, M. S. (2015). Analisis dan Perancangan Aplikasi Sistem Informasi Penggajian Karyawan pada PT Aditya Buana Inter Sungailiat Bangka. Jurnal SIMETRIS $6,277-288$

Mulyadi (2016). Sistem akuntansi (Erlangga: Salemba Empat).

Novena, M. E. (2012). Analisis dan Perancangan Sistem Informasi Akuntansi Penggajian Terkomputerisasi pada PT PD (Kantor Pusat). Jurnal Ilmiah Mahasiswa Akuntansi 01.

Romney, M. B. and Steinbart, P. J. (2017). Sistem informasi akuntansi (Ed. ke-13), and others (ed.).

Saraswati, K. M. (2014). Analisis Sistem Akuntansi Penggajian dan Pengupahan Karyawan dalam Usaha Meningkatkan Pengendalian Intern. Jurnal Adminsitrasi Bisnis 8.

Suryanto (2011). Design dan Analysis: Payroll of Accounting Informastion System. 
Communication and Information Technology 5, 24-26.

Thite, M. and Shandu, K. S. (2014). Where Is My Pay? Critical Success Factors of a Payroll System-System Life Cycle Approach. Australian Journal of Information Systems 18, 149-164.

Widjajanto, N. (2001). Sistem informasi akuntansi (Jakarta: Erlangga).

Conflict of Interest Statement: The authors declare that the research was conducted in the absence of any commercial or financial relationships that could be construed as a potential conflict of interest.

Copyright (C) 2019 and. This is an open-access article distributed under the terms of the Creative Commons Attribution License (CC BY). The use, distribution or reproduction in other forums is permitted, provided the original author(s) and the copyright owner(s) are credited and that the original publication in this journal is cited, in accordance with accepted academic practice. No use, distribution or reproduction is permitted which does not comply with these terms. 